\title{
KUALITAS KIMIA DAN KANDUNGAN KLOROFIL TANAMAN ALFALFA (Medicago sativa L.) DENGAN LAMA PENYINARAN DAN DOSIS DOLOMIT YANG BERBEDA PADA TANAH REGOSOL

\author{
QUALITY OF CHEMICAL AND CHLOROPHYLL CONTENTS OF ALFALFA PLANTS \\ (Medicago sativa L.) WITH LENGHT OF IRRADIATION AND DOSE OF DOLOMITE ON THE \\ REGOSOL SOIL
}

\author{
Hermanto $^{1 *}$, Bambang Suwignyo ${ }^{2}$, dan Nafiatul Umami ${ }^{2}$ \\ ${ }^{1}$ Dinas Pertanian, Ketahanan Pangan dan Perikanan, Mempawah, Kalimantan Barat, 78912 \\ ${ }^{2}$ Fakultas Peternakan, Universitas Gadjah Mada, Yogyakarta, 55281
}

Submitted: 29 February 2016, Accepted: 26 January 2017

\section{INTISARI}

Penelitian ini bertujuan untuk menganalisis kualitas kimia dan kandungan klorofil tanaman alfalfa dengan lama penyinaran dan dosis dolomit yang berbeda pada tanah regosol. Penelitian dilaksanakan di Rumah Kaca Laboratorium IImu Hijauan Makanan Ternak dan Pastura Fakultas Peternakan Universitas Gadjah Mada dari bulan Mei sampai September 2015. Penelitian ini menggunakan Rancangan Acak Lengkap (RAL) pola faktorial $3 \times 3$ dengan dua faktor perlakuan dan masing-masing dengan 4 ulangan. Faktor pertama adalah dosis dolomit (D) dengan 3 perlakuan (D0 $=$ tanpa dolomit, $\mathrm{D} 1=$ dolomit 6 t/ha atau $90 \mathrm{~g} /$ polybag dan D2 = dolomit $12 \mathrm{t} / \mathrm{ha}$ atau $180 \mathrm{~g} /$ polybag). Faktor kedua adalah lama penyinaran (C) dengan 3 perlakuan $(\mathrm{C} 0=$ penyinaran $12 \mathrm{jam}, \mathrm{C} 1=$ penyinaran 14 jam dan $\mathrm{C} 2=$ penyinaran 16 jam). Data hasil penelitian dianalisis secara statistik dengan menggunakan sidik ragam dan hasil yang berpengaruh nyata dilanjutkan dengan uji Duncan pada taraf $5 \%$. Parameter yang diamati adalah analisis proksimat (bahan kering, bahan organik, protein kasar, serat kasar, lemak kasar, abu) dan kandungan klorofil alfalfa. Hasil penelitian menunjukkan bahwa tidak terdapat pengaruh interaksi yang nyata antara perlakuan lama penyinaran dan perlakuan dosis dolomit terhadap kandungan bahan kering, bahan organik, protein kasar, serat kasar, lemak kasar, abu dan kandungan klorofil alfalfa. Perlakuan lama penyinaran berpengaruh nyata $(\mathrm{P}<0,05)$ terhadap kandungan bahan organik dan kadar abu alfalfa. Perlakuan dosis dolomit tidak berpengaruh nyata terhadap semua parameter penelitian.

(Kata kunci: Alfalfa, Dolomit, Lama penyinaran, Tanah regosol)

\section{ABSTRACT}

This study aimed to analyze the quality of chemical and chlorophyll contents of alfalfa plants under different lenghts of irradiation and dose of dolomite on the regosol soil. The experiment was conducted in Greenhouse of the Forage and Pasture Laboratory Faculty of Animal Science University of Gadjah Mada, from May to September 2015. The experiment used a Completely Randomized Design (CRD) $3 \times 3$ based on two factor of treatments and each with four replications. The first factor was dose of dolomite (D) consisted of 3 treatments $(D 0=$ without dolomite, $D 1=$ dolomite $6 \mathrm{t} / \mathrm{hectare}$ or $90 \mathrm{~g} / \mathrm{polybag}$ and $\mathrm{D2}=$ dolomite 12 t/hectare or $180 \mathrm{~g} / \mathrm{polybag}$ ). The second factor was length of irradiation (C) consisted of 3 treatments (CO = irradiating 12 hours, $C 1=$ irradiating 14 hours and C2 = irradiating 16 hours). Data found were subjected to analysis of variance and continued with Duncan test at $5 \%$ level when significant effect was observed. Parameters measured were the proximate analysis (dry matter, organic matter, crude protein, crude fiber, crude fat, ash) and chlorophyll content. The results showed that there was no significant interaction effect between lenght of irradiation and dose of dolomite treatment on dry matter, organic matter, crude protein, crude fiber, crude fat, ash and chlorophyll contents of alfalfa. Lenght of irradiation were significantly affected $(P<0.05)$ in organic matter and ash contents of alfalfa. Dose of dolomite treatment was not significant on all parameters of the study. The results showed that there was no significant influenced of interactionon the contents of fresh weight, dry weight, dry matter, organic matter, crude protein, crude fiber, crude fat, ash and chlorophyll of alfalfa.

(Keywords: Alfalfa, Dolomite, Lenght of irradiation, Regosol soil)

\footnotetext{
* Korespondensi (corresponding author):

Telp. +62 8538702 8267, E-mail: hermantospt@gmail.com
} 


\section{Pendahuluan}

Alfalfa merupakan tanaman liar yang berasal dari hutan, sebelum dibudidayakan oleh manusia. Alfalfa dalam perkembangannya, dibudidayakan untuk memenuhi kebutuhan hijauan bagi ternak di Amerika Serikat, Jepang, Australia dan Korea (Parman, 2007 cit. Suwignyo et al., 2014).

Alfalfa tergolong sumber hijauan pakan yang potensial dimanfaatkan untuk ternak ruminansia karena produksinya tinggi serta didukung nilai nutrisi yang baik dengan kandungan protein kasar berkisar 17,7 24,1\% (Teuber and Phillips, 1998 cit. Sirait et al., 2010). Manfaat alfalfa selain sebagai pakan ternak, juga sebagai bahan suplemen atau obat kesehatan bagi manusia. Salah satu suplemen makanan yang telah banyak dikonsumsi adalah liquid chlorophyll berbahan dasar klorofil daun alfalfa (Mardaningsih et al., 2012). Subantoro et al. (2007) menyatakan bahwa daun tanaman alfalfa mempunyai kandungan klorofil empat kali lipat dibanding dengan tanaman sayuran lainnya.

Pertumbuhan alfalfa membutuhkan sinar matahari dan kadar kapur yang cukup, tahan temperatur tinggi tetapi tidak tahan kelembaban tinggi, serta memerlukan drainase baik, $\mathrm{pH}$ 6,5 atau lebih dengan kesuburan tanah yang baik (Agricultural Experiment Station and Cooperative Extension Service, 1998). Cahaya merupakan faktor lingkungan terpenting, mempunyai peranan yang mendasar pada proses fotosintesis di dalam metabolisme tanaman. Proses perkembangan yang dikendalikan cahaya dijumpai pada semua tahap pertumbuhan dari perkecambahan biji, pertumbuhan sampai berbunga (Fitter and Hay, 1992). Cahaya sebagai sumber energi untuk reaksi anabolik fotosintesis akan berpengaruh terhadap laju fotosintesis. Penyinaran yang panjang pada tanaman akan meningkatkan jumlah cahaya yang diterima oleh setiap luasan permukaan daun dalam jangka waktu tertentu, sehingga laju fotosintesis dan sintesis karbohidrat meningkat.

Pertumbuhan dan perkembangan tanaman mempengaruhi produksi dan kualitas tanaman. Fase pertumbuhan merupakan faktor terbesar dalam menentukan kualitas produksi hijauan ketika dipanen, bahan kering alfalfa mengalami peningkatan secara terus menerus mulai awal pertumbuhan sampai pada saat sebagian tanaman mulai berbunga. Cahaya merupakan faktor lingkungan terpenting, mempunyai peranan yang mendasar pada proses fotosintesis di dalam metabolisme tanaman. Proses perkembangan yang dikendalikan cahaya dijumpai pada semua tahap pertumbuhan dari perkecambahan biji, pertumbuhan sampai berbunga (Fitter and Hay, 1992). Cahaya sangat penting dalam proses fotosintesis karena berperan sebagai sumber energi pembentuk bahan kering tanaman. Proses fotosintesis akan berlangsung dengan baik jika cahaya matahari yang jatuh ke permukaan tanaman melalui klorofil optimal dan akan terganggu jika sebaliknya (Sawen, 2012).

Faktor lain yang dapat mendukung pertumbuhan dan perkembangan tanaman alfalfa adalah dengan pemberian dolomit $\left(\mathrm{CaMg}\left(\mathrm{CO}_{3}\right)_{2}\right)$ sebagai sumber kalsium dan magnesium bagi tanaman. Mineral kalsium berfungsi untuk merangsang perkembangan akar dan daun (Winarso, 2009 cit. Silahooy, 2012), sedangkan magnesium merupakan komponen utama dari klorofil yang sangat berperanan penting dalam proses fotosintesis (Barnes et al., 2007), dan semakin meningkatnya sifat fisik dan unsur hara terutama kalsium dan magnesium maka dapat memacu turgol sel dan pembentukan khlorofil sehingga proses fotosintesis menjadi lebih meningkat dan produk dari fotosintesis juga meningkat (Sumaryo dan Suryono, 2000). Berdasarkan hal tersebut, maka perlu dilakukan kajian atau penelitian untuk pengembangan tanaman alfalfa di daerah tropis.

Penelitian ini bertujuan untuk menganalisis kualitas kimia dan kandungan klorofil tanaman alfalfa dengan lama penyinaran dan dosis dolomit yang berbeda pada tanah regosol.

\section{Materi dan Metode}

Penelitian ini dilaksanakan selama 4 bulan yang dimulai dari bulan Mei sampai September 2015, bertempat di Rumah Kaca Laboratorium Hijauan Makanan Ternak dan Pastura Fakultas Peternakan Univesitas Gadjah Mada, Yogyakarta.

\section{Materi}

Alat. Peralatan yang digunakan dalam penelitian ini meliputi peralatan lapangan dan peralatan laboratorium. Peralatan lapangan 
antara lain: polybag ukuran 45 x $45 \mathrm{~cm}$, plastik mulsa, timbangan, bambu, tali rafia, cangkul, gergaji, parang, pisau, gunting, ember, gayung, sprayer, kabel, lampu neon cool daylight 36 watt, switch timer, rol meter, alat tulis, kertas label, penggaris dan kamera.

Bahan. Bahan yang digunakan adalah biji alfalfa, dolomit, pupuk organik (daun leguminosa) produksi dari KP4 Universitas Gadjah Mada Yogyakarta, air dan tanah regosol dari kebun Laboratorium Hijauan Makanan Ternak dan Pastura Fakultas Peternakan Universitas Gadjah Mada, Yogyakarta.

\section{Metode}

Rancangan percobaan. Penelitian ini menggunakan Rancangan Acak Lengkap (RAL) pola faktorial $3 \times 3$ dengan dua faktor perlakuan dan empat ulangan. Faktor pertama adalah dosis dolomit (D) terdiri dari 3 taraf, yaitu: $\mathrm{D0}=$ tanpa dolomit, $\mathrm{D} 1=$ dolomit $6 \mathrm{t} / \mathrm{ha}$ atau $90 \mathrm{~g} /$ polybag dan D2 = dolomit 12 t/ha atau $180 \mathrm{~g} /$ polybag. Faktor kedua adalah lama penyinaran $(C)$ terdiri dari 3 taraf, yaitu: $\mathrm{C0}=$ penyinaran selama 12 jam (cahaya matahari), $\mathrm{C} 1$ = penyinaran selama 14 jam (cahaya matahari 12 jam + 2 jam lampu neon), dan $\mathrm{C} 2$ = penyinaran selama 16 jam (cahaya matahari 12 jam +4 jam lampu neon). Dari kedua faktor tersebut diperoleh 9 kombinasi perlakuan dengan 4 ulangan, sehingga terdapat 36 satuan percobaan.

Pelaksanaan penelitian. Pelaksanaan penelitian yang dilakukan seperti persiapan media tanam dengan 3 jenis campuran berdasarkan penggunaan dolomit, yakni: tanah regosol $5 \mathrm{~kg}+$ pupuk daun $5 \mathrm{~kg}+$ tanpa dolomit sebanyak 12 polybag, tanah regosol 5 $\mathrm{kg}+$ pupuk daun $5 \mathrm{~kg}+$ dolomit $90 \mathrm{~g} /$ polybag, tanah regosol $5 \mathrm{~kg}+$ pupuk daun $5 \mathrm{~kg}+$ dolomit 180 g/polybag. Pupuk daun digunakan sebagai pupuk dasar dengan perbandingan 1:1 dengan tanah regosol. Penanaman biji dilakukan pada hari keenam dengan cara ditanam langsung pada polybag yang sudah disiapkan, dengan kedalaman sekitar $1 \mathrm{~cm}$ kemudian ditutup lagi dengan tanah. Kegiatan pemeliharaan meliputi penyiraman, penjarangan, penyiangan dan pengelolaan hama dan penyakit. Penambahan cahaya pada malam hari mulai diberikan pada umur 3 minggu setelah tanam (MST) menggunakan lampu neon cool daylight 36 watt yang dipasang setinggi 1,5 meter di atas permukaan tanah. Pemanenan dilakukan pada umur 11 MST.
Variabel penelitian. Variabel yang diamati meliputi analisis proksimat berupa pengukuran kadar bahan kering, bahan organik, protein kasar, serat kasar, lemak kasar dan abu (AOAC, 1970), serta pengukuran kandungan klorofil alfalfa berdasarkan metode Arnon (1949).

\section{Analisis data}

Data hasil penelitian dianalisis secara statistik dengan menggunakan sidik ragam dan hasil yang berpengaruh nyata dilanjutkan dengan uji Duncan pada taraf 5\% (Steel dan Torrie, 1995).

\section{Hasil dan Pembahasan}

\section{Analisis proksimat}

Analisis proksimat merupakan pengujian kimiawi untuk mengetahui kandungan nutrien suatu bahan baku pakan atau pakan, yaitu kadar air, abu, protein kasar, serat kasar, lemak kasar dan bahan ekstrak tanpa nitrogen (AOAC, 1970).

Bahan kering. Bahan kering adalah berat tetap suatu sampel setelah dipanaskan pada suhu $105^{\circ} \mathrm{C}$ dalam oven selama beberapa jam sehingga semua air yang ada menguap (AOAC, 1970). Hasil analisis ragam menunjukkan bahwa pada perlakuan lama penyinaran dan dosis dolomit tidak berpengaruh nyata terhadap kandungan bahan kering (\%) alfalfa dan tidak terdapat interaksi yang nyata antara kedua perlakuan tersebut. Data rerata kandungan bahan kering alfalfa pada umur 11 minggu setelah tanam (MST) disajikan dalam Tabel 1.

Pada Tabel 1, terlihat bahwa kandungan bahan kering tertinggi adalah pada sebesar 21,16\% C2D0 dan terendah $15,17 \%$ pada COD1. Tingginya kandungan bahan kering dalam penelitian ini diduga karena umur tanaman saat pemotongan sudah cukup tua (11 MST). Sebagaimana yang dikemukakan oleh Beever et al. (2000) cit. Seseray et al. (2013) bahwa proporsi bahan kering yang dikandung oleh tanaman berubah seiring dengan umurnya, makin tua tanaman maka makin sedikit kandungan airnya dan proporsi dinding sel lebih tinggi dibandingkan dengan isi sel. Apabila kandungan dinding sel yang dimiliki tanaman lebih besar, maka tanaman akan lebih banyak mengandung bahan kering.

Meningkatnya kandungan bahan kering merupakan indikator pertumbuhan yang utama paling sering digunakan, di mana 
Tabel 1. Rerata kandungan bahan kering (\%) tanaman alfalfa pada umur $11 \mathrm{MST}$ (the average dry matter content (\%) alfalfa plants at the age of 11 week after planting)

\begin{tabular}{lcccc}
\hline \hline \multirow{2}{*}{$\begin{array}{c}\text { Lama penyinaran } \\
\text { (length of irradiation) }\end{array}$} & \multicolumn{3}{c}{ Dosis dolomit (dolomite doses) } & Rerata C \\
\cline { 2 - 4 } (average C) \\
\hline C0 (12 jam) (12 hours) & D0 (0 ton/ha) & D1 (6 ton/ha) & D2 (12 ton/ha) & $17,95 \pm 2,35$ \\
C1 (14 jam) (14 hours) & $19,72 \pm 1,90$ & $15,17 \pm 0,57$ & $18,98 \pm 0,29$ & $17,45 \pm 2,21$ \\
C2 (16 jam) (16 hours) & $17,50 \pm 1,58$ & $20,95 \pm 1,42$ & $19,30 \pm 2,07$ \\
Rerata D (average D) & $21,16 \pm 1,32$ & $20,40 \pm 1,58$ & $17,73 \pm 1,14$ & $19,76 \pm 1,93$ \\
\hline
\end{tabular}

Tanda (-) menunjukkan tidak terdapat interaksi.

bahan kering merupakan akumulasi dari hasil fotosintesis, serapan unsur hara dan air yang diolah melalui proses biosintesis yang meningkat seiring dengan bertambahnya umur (Sitompul dan Guritno, 1995).

Bahan organik. Hasil analisis ragam menunjukkan bahwa perlakuan lama penyinaran berpengaruh nyata $(P<0,05)$ terhadap kandungan bahan organik alfalfa, sedangkan perlakuan dosis dolomit tidak berpengaruh nyata terhadap kandungan bahan organik alfalfa. Tidak terdapat interaksi yang nyata antara kedua perlakuan. Rerata kandungan bahan organik alfalfa tersaji dalam Tabel 2.

Pada Tabel 2, terlihat bahwa kandungan bahan organik tertinggi sebesar $89,18 \%$ pada penyinaran 16 jam, terendah sebesar $88,12 \%$ pada penyinaran 12 jam. Hasil uji Duncan menunjukkan bahwa terdapat perbedaan yang nyata $(P<0,05)$ antara perlakuan penyinaran 16 jam dengan penyinaran $12 \mathrm{jam}$. Peningkatan kandungan bahan organik dipengaruhi oleh lamanya penyinaran, dimana dengan intensitas cahaya yang tinggi akan memacu laju fotosintesis menjadi optimum, sehingga komponen-komponen sel yang mendukung berat kering tanaman meningkat. Peningkatan produksi BK akan diikuti dengan meningkatnya produksi bahan organik (Wahyuni dan Kamaliyah, 2009).

Protein kasar. Hasil analisis ragam menunjukkan bahwa perlakuan lama penyinaran dan dosis dolomit tidak berpengaruh nyata terhadap kandungan protein kasar (\%) alfalfa dan tidak terdapat interaksi yang nyata antara kedua perlakuan tersebut. Data rerata kandungan protein kasar (\%) alfalfa disajikan dalam Tabel 3.

Pada Tabel 3 terlihat bahwa kandungan protein kasar tertinggi sebesar $21,13 \%$ pada C2D2, terendah sebesar $17,09 \%$ pada C2D0. Nilai kandungan protein kasar dalam penelitian ini tergolong cukup baik, sebagaimana yang dilaporkan oleh Earthnote (2004) cit. Sirait et al. (2010) bahwa alfalfa sebagai sumber hijauan pakan ternak dengan nilai nutrisi yang baik, memiliki protein kasar berkisar 17,7 - 24,1\%.

Kandungan protein kasar alfalfa dalam beberapa penelitian lain cukup bervariasi, seperti yang dilaporkan oleh Wahyuni dan Kamaliyah (2009) sebesar $19,54 \%$ pada umur pemotongan 80 hari dan Sirait et al. (2010) sekitar $16,02 \%$ yang dipotong pada umur 100 hari. Perbedaan nilai kandungan protein kasar setiap tanaman dipengaruhi oleh banyak faktor, diantaranya spesies tanaman, umur panen, jenis tanah maupun kesuburan lahan sebagaimana dikemukakan Sirait et al. (2010).

Serat kasar. Hasil analisis ragam menunjukkan bahwa pada perlakuan lama penyinaran dandosis dolomit tidak berpengaruh nyata terhadap serat kasar (\%)alfalfa dan tidak terdapat interaksi yang nyata antara kedua perlakuan tersebut. Data

Tabel 2. Rerata kandungan bahan organik (\%) tanaman alfalfa pada umur $11 \mathrm{MST}$ (the average organic matter content (\%) alfalfa plants at the age of 11 week after planting)

\begin{tabular}{|c|c|c|c|c|}
\hline \multirow{2}{*}{$\begin{array}{l}\text { Lama penyinaran } \\
\text { (length of iiradiation) }\end{array}$} & \multicolumn{3}{|c|}{ Dosis dolomit (dolomit doses) } & \multirow{2}{*}{$\begin{array}{c}\text { Rerata C } \\
\text { (average C) }\end{array}$} \\
\hline & D0 (0 ton/ha) & D1 (6 ton/ha) & D2 (12 ton/ha) & \\
\hline C0 (12 jam) (12 hours) & $88,30 \pm 0,85$ & $88,10 \pm 0,13$ & $87,97 \pm 0,53$ & $88,12 \pm 0,48^{a}$ \\
\hline C1 (14 jam) (14 hours) & $88,80 \pm 0,17$ & $88,80 \pm 0,44$ & $88,80 \pm 0,25$ & $88,80 \pm 0,24^{a b}$ \\
\hline C2 (16 jam) (16 hours) & $89,21 \pm 0,56$ & $89,60 \pm 0,92$ & $88,74 \pm 0,93$ & $89,18 \pm 0,74^{b}$ \\
\hline Rerata D (average D) & $88,77 \pm 0,61$ & $88,83 \pm 0,82$ & $88,50 \pm 0,64$ & $(-)$ \\
\hline
\end{tabular}


Tabel 3. Rerata kandungan protein kasar (\%) alfalfa pada umur $11 \mathrm{MST}$ (the average crude protein content (\%) alfalfa at the age of 11 week after planting)

\begin{tabular}{|c|c|c|c|c|}
\hline \multirow{2}{*}{$\begin{array}{l}\text { Lama penyinaran } \\
\text { (lenght of irradiation) }\end{array}$} & \multicolumn{3}{|c|}{ Dosis dolomit (dolomit doses) } & \multirow{2}{*}{$\begin{array}{c}\text { Rerata C } \\
(\text { average } C)\end{array}$} \\
\hline & D0 (0 ton/ha) & D1 (6 ton/ha) & D2 (12 ton/ha) & \\
\hline C0 (12 jam) (12 hours) & $18,46 \pm 1,38$ & $20,94 \pm 0,63$ & $19,91 \pm 0,59$ & $19,77 \pm 1,33$ \\
\hline C1 (14 jam) (14 hours) & $20,40 \pm 0,91$ & $18,99 \pm 0,76$ & $20,45 \pm 1,26$ & $19,95 \pm 1,07$ \\
\hline C2 (16 jam) (16 hours) & $17,09 \pm 3,17$ & $20,53 \pm 1,05$ & $21,13 \pm 1,09$ & $19,58 \pm 2,51$ \\
\hline Rerata D (average D) & $18,65 \pm 2,19$ & $20,15 \pm 1,12$ & $20,50 \pm 0,96$ & $(-)$ \\
\hline
\end{tabular}

Tanda (-) menunjukkan tidak terdapat interaksi.

rerata kandungan serat kasar (\%) alfalfa tersaji dalam Tabel 4.

Pada Tabel 4, terlihat bahwa kandungan serat kasar tertinggi sebesar $34,75 \%$ pada C2D1 dan terendah sebesar $30,69 \%$ pada C2D2. Tingginya kandungan serat kasar pada alfalfa, diduga karena umur tanaman yang cukup tua yakni dipanen umur 11 MST. Gardner et al. (2008) menyatakan bahwa semakin tua umur pemanenan, maka sel pada tanaman memiliki lebih banyak kesempatan untuk menyusun serabut dinding selnya sehingga kadar serat kasar yang merupakan struktur utama dinding sel menjadi semakin banyak jumlahnya.

Lemak kasar. Hasil analisis ragam menunjukkan bahwa pada perlakuan lama penyinaran dan dosis dolomit tidak berpengaruh nyata terhadap lemak kasar (\%) alfalfa dan tidak terdapat interaksi yang nyata antara kedua perlakuan tersebut. Rerata kandungan lemak kasar (\%) alfalfa disajikan dalam Tabel 5 .
Pada Tabel 5, terlihat bahwa kandungan lemak kasar tertinggi sebesar $10,41 \%$ pada C1D0, terendah sebesar $8,79 \%$ pada CODO. Tingginya kandungan lemak kasar ini, diduga karena umur tanaman saat pemotongan yang sudah cukup tua serta dalam kondisi sudah berpolong sekitar $27 \%$. Sebagaimana yang dikemukakan oleh Astuti (2011) bahwa semakin tua umur tanaman semakin banyak cadangan energi dalam bentuk lemak kasar yang ditimbun di daun. Dwidjoseputro (1985) menjelaskan bahwa biji dalam suatu tumbuhan umumnya mempunyai kandungan lemak yang lebih tinggi.

Kadar abu. Hasil analisis ragam menunjukkan bahwa perlakuan lama penyinaran berpengaruh nyata $(P<0,05)$ terhadap kadar abu alfalfa, sedangkan perlakuan dosis dolomit tidak berpengaruh nyata terhadap kadar abu alfalfa. Tidak terdapat interaksi yang nyata antara kedua perlakuan tersebut. Data rerata kadar abu (\%) alfalfa disajikan dalam Tabel 6 .

Tabel 4. Rerata kandungan serat kasar (\%) tanaman alfalfa pada umur $11 \mathrm{MST}$ (the average content of crude fiber (\%) alfalfa plants at the age of 11 week after planting)

\begin{tabular}{|c|c|c|c|c|}
\hline \multirow{2}{*}{$\begin{array}{l}\text { Lama penyinaran } \\
\text { (lenght of irradiation) }\end{array}$} & \multicolumn{3}{|c|}{ Dosis dolomit (dolomit doses) } & \multirow{2}{*}{$\begin{array}{c}\text { Rerata C } \\
\text { (average C) }\end{array}$} \\
\hline & D0 (0 ton/ha) & D1 (6 ton/ha) & D2 (12 ton/ha) & \\
\hline C0 (12 jam) (12 hours) & $31,74 \pm 0,05$ & $31,63 \pm 0,45$ & $31,27 \pm 0,71$ & $31,55 \pm 0,43$ \\
\hline C1 (14 jam) (14 hours) & $30,99 \pm 0,95$ & $30,91 \pm 1,15$ & $31,05 \pm 1,19$ & $30,98 \pm 0,86$ \\
\hline C2 (16 jam) (16 hours) & $32,06 \pm 2,38$ & $34,75 \pm 2,17$ & $30,69 \pm 1,20$ & $32,50 \pm 2,40$ \\
\hline Rerata D (average D) & $31,59 \pm 1,25$ & $32,43 \pm 2,14$ & $31,00 \pm 0,86$ & $(-)$ \\
\hline
\end{tabular}

Tabel 5. Rerata kandungan lemak kasar (\%) tanaman alfalfa pada umur $11 \mathrm{MST}$ (the average crude fat content (\%) alfalfa plants at the age of 11 week after planting)

\begin{tabular}{lcccc}
\hline \hline \multirow{2}{*}{$\begin{array}{c}\text { Lama penyinaran } \\
\text { (lenght of irradiation) }\end{array}$} & \multicolumn{3}{c}{ Dosis dolomit (dolomit doses) } & \multirow{2}{*}{$\begin{array}{c}\text { Rerata C } \\
\text { (average C) }\end{array}$} \\
\cline { 2 - 4 } C0 (12 jam) (12 hours) & D0 (0 ton/ha) & D1 (6 ton/ha) & D2 (12 ton/ha) & \\
C1 (14 jam) (14 hours) & $8,79 \pm 0,08$ & $9,15 \pm 0,62$ & $10,08 \pm 1,22$ & $9,34 \pm 0,85$ \\
C2 (16 jam) (16 hours) & $10,41 \pm 0,88$ & $10,05 \pm 0,35$ & $9,56 \pm 0,90$ & $10,00 \pm 0,70$ \\
Rerata D (average D) & $10,19 \pm 0,84$ & $9,45 \pm 0,10$ & $9,72 \pm 0,28$ & $9,78 \pm 0,52$ \\
\hline
\end{tabular}

Tanda (-) menunjukkan tidak terdapat interaksi. 
Tabel 6. Rerata kadar abu (\%) tanaman alfalfa pada umur $11 \mathrm{MST}$ (the average ash content (\%) alfalfa plants at the age of 11 week after planting)

\begin{tabular}{ccccc}
\hline \hline \multirow{2}{*}{$\begin{array}{c}\text { Lama penyinaran } \\
\text { (lenght of irradiation) }\end{array}$} & \multicolumn{3}{c}{ Dosis dolomit (dolomit doses) } & \multirow{2}{*}{$\begin{array}{c}\text { Rerata C } \\
\text { (average C) }\end{array}$} \\
\cline { 2 - 4 } C0 (12 jam) (12 hours) & $11,70 \pm 0,85$ & $11,91 \pm 0,13$ & $12,04 \pm 0,53$ & $11,88 \pm 0,48^{\mathrm{a}}$ \\
C1 (14 jam) (14 hours) & $11,20 \pm 0,17$ & $11,20 \pm 0,44$ & $11,20 \pm 0,25$ & $11,20 \pm 0,25^{\mathrm{ab}}$ \\
C2 (16 jam) (16 hours) & $10,80 \pm 0,56$ & $10,40 \pm 0,92$ & $11,26 \pm 0,93$ & $10,82 \pm 0,74^{\mathrm{b}}$ \\
Rerata D (average $D)$ & $11,23 \pm 0,61$ & $11,17 \pm 0,82$ & $11,50 \pm 0,64$ & $(-)$ \\
a,b,c $\begin{array}{l}\text { Superscript yang berbeda pada baris atau kolom yang sama, menunjukkan perbedaan yang nyata }(P<0,05) \\
\text { (different superscripts at the same row or column indicate significant differences }(P<0.05)) .\end{array}$ \\
Tanda (-) menunjukkan tidak terdapat interaksi.
\end{tabular}

Tabel 7. Rerata kandungan klorofil (mg/g) tanaman alfalfa pada umur $11 \mathrm{MST}$ (the average chlorophyll content (mgg) alfalfa plants at the age of 11 week after planting)

\begin{tabular}{lcccc}
\hline \hline \multirow{2}{*}{$\begin{array}{c}\text { Lama penyinaran } \\
\text { (length of Irradiation) }\end{array}$} & \multicolumn{3}{c}{ Dosis dolomit (dolomit doses) } & \multirow{2}{*}{$\begin{array}{c}\text { Rerata C } \\
\text { (average C) }\end{array}$} \\
\cline { 2 - 4 } C0 (12 jam) (12 hours) & D0 (0 ton/ha) & D1 (6 ton/ha) & D2 (12 ton/ha) & $0,89 \pm 0,17$ \\
C1 (14 jam) (14 hours) & $0,99 \pm 0,08$ & $0,76 \pm 0,20$ & $0,93 \pm 0,18$ & $0,86 \pm 0,09$ \\
C2 (16 jam) (16 hours) & $0,94 \pm 0,08$ & $0,81 \pm 0,11$ & $0,82 \pm 0,06$ & $0,95 \pm 0,07$ \\
Rerata D (average D) & $0,97 \pm 0,04$ & $0,89 \pm 0,08$ & $1,00 \pm 0,08$ & $(-)$ \\
\hline
\end{tabular}

Tanda (-) menunjukkan tidak terdapat interaksi.

Pada Tabel 6 terlihat bahwa kadar abu tertinggi sebesar $11,88 \%$ pada perlakuan penyinaran 12 jam dan terendah sebesar $10,82 \%$ pada perlakuan penyinaran 16 jam. Hasil uji Duncan menunjukkan bahwa terdapat perbedaan yang nyata $(P<0,05)$ antara perlakuan penyinaran 12 jam dengan perlakuan penyinaran 16 jam. Nilai kadar abu menggambarkan kandungan dari berbagai oksida mineral sesuai dengan macam mineral yang terkandung di dalam bahannya (Kamal, 1998). Semakin tinggi kandungan abu suatu bahan pangan maka kandungan mineral yang dihasilkan semakin banyak. Pearson and Ison (1987) cit. Astuti (2011) menyatakan bahwa kadar abu (mineral) pada tanaman lebih tinggi pada awal pertumbuhan dan menurun seiring dengan meningkatnya umur tanaman.

\section{Kandungan klorofil}

Hasil analisis ragam menunjukkan bahwa perlakuan lama penyinaran dan dosis dolomit tidak berpengaruh nyata terhadap jumlah klorofil $(\mathrm{mg} / \mathrm{g})$ alfalfa dan tidak terdapat interaksi yang nyata antara kedua perlakuan tersebut. Data rerata jumlah klorofil $(\mathrm{mg} / \mathrm{g})$ alfalfa disajikan dalam Tabel 7 .

Pada Tabel 7 terlihat bahwa kandungan klorofil pada alfalfa tertinggi pada C2D2 sebesar $1,00 \mathrm{mg} / \mathrm{g}$, terendah pada COD1 sebesar $0,76 \mathrm{mg} / \mathrm{g}$. Kandungan klorofil yang dihasilkan dalam penelitian ini lebih rendah jika dibandingkan dengan apa yang dilaporkan oleh Subantoro et al. (2012) sebesar 3,15 mg/g dan Setyanti et al. (2013) sebesar $4,46 \mathrm{mg} / \mathrm{g}$. Banyak faktor yang mempengaruhi pembentukan klorofil, seperti yang dikemukakan oleh Dwijoseputro (1992) cit. Setyanti et al. (2013) bahwa pembentukan klorofil dipengaruhi oleh beberapa faktor yaitu faktor genetik tanaman, intensitas cahaya, oksigen, karbohidrat, unsur hara, air, dan temperatur.

\section{Kesimpulan}

Hasil penelitian dapat disimpulkan bahwa dengan penambahan lama penyinaran (16 jam) pada tanaman alfalfa dapat meningkatkan kandungan bahan organik dan abu. Tanaman alfalfa kurang responsif terhadap perlakuan dosis dolomit.

\section{Ucapan Terima Kasih}

Penulis mengucapkan terima kasih kepada Pemda Kabupaten Mempawah, Kalimantan Barat, serta rekan tim alfalfa (Marta dan Mona) dan teman-teman yang sudah memberikan dukungan, motivasi dan bantuan selama studi dan penelitian ini.

\section{Daftar Pustaka}

Agricultural Experiment Station and Cooperative Extension Service. 1998. Alfalfa Production Handbook. Kansas State University Manhattan, Kansas. 
AOAC. 1970. Official Methods of Analysis of the Association of Official Analytical Chemist. Association of Official Analytical Chemist, Washington, DC.

Arnon, D. I. 1949. Copper enzymesin isolated chloroplasts polyphenol oxidase in Beta vulgaris. Plant Physiol. 24: 1-15.

Astuti, N. 2011. Pengaruh umur pemotongan terhadap kandungan nutrien rumput raja (King grass). Jurnal Agribisnis 2: 917.

Barnes, R. F., C. J. Nelson, K. J. Moore, and M. Collins. 2007. Forages: The Science of Grassland Agriculture. Blackwell Publishing Professional, USA.

Dwidjeseputro. 1985. Pengantar Fisiologi Tumbuhan. PT. Gramedia, Jakarta.

Fitter, A. H and R. K. M. Hay. 1992. Enviromental Physiology of Plants. Diterjemahkan oleh Sri Andani dan E. D. Purbayanti. Cetakan kedua. Gadjah Mada University Press, Yogyakarta.

Gardner, F. P., R. B. Pearce, and R. L. Mitcheli. 2008. Fisiologi Tanaman Budidaya. Diterjemahkan oleh Herawati Susilo. UI Press, Jakarta.

Kamal, M. 1998. Nutrisi Ternak I. Rangkuman. Laboratorium Makanan Ternak, Jurusan Nutrisi dan Makanan Ternak. Fakultas Peternakan, Universitas Gadjah Mada, Yogyakarta.

Mardaningsih, F., M. A. M. Andriani, dan Kawiji. 2012. Pengaruh konsentrasi etanol dan suhu spray dryer terh adap karakteristik bubuk klorofil daun alfalfa (Medicago sativa L.) dengan menggunakan binder maltodekstrin. Jurnal Teknosains Pangan 1: 110-117.

Sawen, D. 2012. Pertumbuhan rumput gajah (Pennisetum purpureum) dan benggala (Panicum maximum) akibat perbedaan intensitas cahaya. Agrinimal 2: 17-20.

Seseray, D. S., B. Santoso, dan M. N. Lekitoo. 2013. Produksi rumput gajah (Pennisetum purpureum) yang diberi pupuk $\mathrm{N}, \mathrm{P}$, dan $\mathrm{K}$ dengan Dosis 0,50 dan $100 \%$ pada devoliasi hari ke-45. Sains Peternakan 11: 49-55.

Setyanti, Y. H., S. Anwar, dan Widyati-Slamet. 2013. Karakteristik fotosintetik dan serapan fosfor hijauan alfalfa pada tinggi pemotongan dan pemupukan nitrogen yang berbeda. Anim. Agric. J. 2: 86-96.

Silahooy, C. 2012. Efek dolomit dan SP-36 terhadap bintil akar, serapan $\mathrm{N}$ dan hasil kacang tanah pada tanah kambisol. Agrologia 1: 91-98.

Sirait, J., M. Syawal, dan K. Simanihuruk. 2010. Tanaman Alfalfa Adaptif Dataran Tinggi Iklim Basah sebagai Sumber Pakan: Morfologi, Produksi dan Palatabilitas. Seminar Nasional Teknologi Peternakan dan Veteriner, 2010.

Sitompul, S. M. dan B. Guritno. 1995. Analisis Pertumbuhan Tanaman. Gadjah Mada University Press, Yogyakarta.

Steel, R. G. D. and J. H. Torrie. 1995. Prinsip dan Prosedur Statistika Suatu Pendekatan Biometrik. PT. Gramedia Pustaka Utama, Jakarta.

Subantoro, R., P. Yudono, dan B. Suwignyo. 2012. Pertumbuhan dan hasil tiga varietas alfalfa (Medicago sativa L.) dengan perlakuan tiga macam rhizobium pada media tanam regosol asal Banguntapan. IImu Pertanian 15: 69-84.

Subantoro, R., S. Wahyuningsih, dan R. Prabowo. 2007. Pengaruh GA-3, kompos, pupuk organik cair dan TSP terhadap pertumbuhan dan perkembangan tanaman alfalfa. Mediagro 67: 67-80.

Sumaryo dan Suryono. 2000. Pengaruh dosis pupuk dolomit dan SP-36 terhadap jumlah bintil akar dan hasil tanaman kacang tanah di tanah latosol. Agrosains 2: 54-58.

Suwignyo, B., R. Subantoro, dan P. Yudono. 2014. Nutrition values and digestibility of three varieties alfalfa (Medicago sativa L.) were inoculated with rhizobium assorted. Proceedings of the $16^{\text {th }}$ AAAP Animal Science Congress Vol. II 10-14 November 2014, Gadjah Mada University, Yogyakarta.

Wahyuni, R. D. dan S. N. Kamaliyah. 2009. Studi tentang pola produksi alfalfa tropis (Medicago sativa L.). Jurnal IImuilmu Peternakan 19: 20-27. 